\title{
TWO NEW CHAMAECYTISUS SPECIES (LEGUMINOSAE-PAPILIONOIDEAE) FROM ALBANIA, WITH AN OVERVIEW ON THE CH. RATISBONENSIS AND CH. ERIOCARPUS SPECIES GROUPS
}

\author{
Dániel PIF Kó* and Zoltán BARINA \\ Department of Botany, Hungarian Natural History Museum \\ H-1431 Budapest, Pf. 137, Hungary; *pifko@bot.nbmus.hu
}

Pifkó, D. \& Barina, Z. (2016): Two new Chamaecytisus species (Leguminosae-Papilionoideae) from Albania, with an overview on the Ch. ratisbonensis and Ch. eriocarpus species groups. - Studia bot. hung. 47(1): 163-178.

\begin{abstract}
Two new species, Chamaecytisus korabensis and Ch. pseudojankae, both from Albania, are described and illustrated here. The relationship of the new taxa to $C h$. ratisbonensis and $C h$. eriocarpus agg. is discussed. Ch. korabensis is an endemic species of eastern Albania and related to the Eastern European Ch. ratisbonensis agg. Ch.pseudojankae is an endemic species of the Thate and Galičica Mountain ranges, and morphologically it is between Ch. austriacus and Ch. eriocarpus agg. Additionally, the names Cytisus absinthioides and C. pygmaeus are lectotypified.
\end{abstract}

Key words: Fabaceae, endemic species, lectotype, taxonomy

\section{INTRODUCTION}

The genus Chamaecytisus is distributed from the Canary Islands to Anatolia, occurring throughout the entire Mediterranean region and Europe except for the western and northern parts. Up to now, approximately 350 taxa have been described in the genus Chamaecytisus Link (incl. ca 120 species). Due to taxonomic and nomenclatural reasons more than 750 related names are present in the literature (PifKó 2015).

The treatment of Chamaecytisus taxa is highly variable in monographs, thus the clear elucidation of the known taxa, based on type material, is necessary when describing new species. Most of the Chamaecytisus taxa have a continuous distribution, and isolated occurrences far from this area are usually the result of identification errors, misapplications of names or use of atypical and fragmented specimens of populations. Similar taxa, belonging to the same species groups are more or less vicariant. Occasionally hybrid zones are known, where transitional forms can be observed. Some of these populations are so diverse in some characters (colour of flowers, hair types of leaves) that the populations are published (or 
described) under 4-5 different taxon names based on single collected specimens, thus describing new taxa from these populations is not recommended (PIFKó 2009, 2010, PIFKó and PAPP 2006).

Two new species belonging to none of the species groups (Ch. albus (Hacq.) Rothm., Ch. austriacus (L.) Link, Ch. eriocarpus (Boiss.) Rothm., Ch. ratisbonensis (Schaeff.) Rothm., Ch. rochelii (Wierzb.) Rothm., Ch. triflorus (Lam.) Skalická, etc.) are described here from Albania. They clearly differ from the Balkan endemic Chamaecytisus taxa (Ch. tommasinii (Vis.) Rothm., Ch. leiocarpus (A. Kern.) Rothm., Ch. frivaldszkyanus (Degen) Kuzmanov, etc.). Both are morphologically uniform in their populations and markedly differ from the sympatric Chamaecytisus taxa, thus their primary hybrid origin can be excluded. The present description of the new species forms part of our work on the revision of the genus Chamaecytisus in the Balkans.

\section{MATERIAL AND METHODS}

Chamaecytisus Link is regarded here as a monophyletic, morphologically uniform, separate genus, contrary to Cristofolini's treatment of Chamaecytisus as the section Tubocytisus of Cytisus (CRISTOFOLINI 1991, CrIstofolini and Troia 2006).

Between 2004 and $2013 \mathrm{ca} 100$ populations of the genus were studied in Albania (BARINA and Pifkó 2011, BARINa et al. 2009, 2013, Pifkó and BARINA 2011); their vouchers are deposited in BP. Revisions of the Chamaecytisus material, including type specimens, have been made using specimens from the following herbaria (abbreviations follow THIERs 2008+): BP, BEO, BEOU, KRA, KRAM, KW, PR, PRC, SO, SOM, W, WU and the collection of University of Tirana (Tirana, Albania; abbreviated here as TIR); additionally, we consulted with the digital collections of the following herbaria: B-W, FR, GOET, HAL, P.

\section{RESULTS}

Chamaecytisus korabensis Pifkó et Barina, sp. nov.

(Fig. 1)

Holotype: Albania, County of Dibër (Rrethi i Dibrës), Mali i Bardhë Mts, near peak Maja e Pelpenikut, above village Sllatinë; on evaporites, N $41.78419^{\circ}$, E 20.45978 , 1,928 m; leg. Z. Barina and D. Pifkó, 17.06.2013; coll. nr. 22354, BP 759110.

Isotypes: BP 759111. 
Description - Low shrub or subshrub, 10-20 cm tall. Young branches and petioles with appressed or erect hairs. Leaves trifoliate, green; leaflets ovate or obovate, more or less mucronate, small, $0.2-0.3 \mathrm{~cm}$ wide and $0.7-1 \mathrm{~cm}$ long. Lower surface more or less densely hairy, upper surface sparsely hairy, with short appressed hairs. Plant without sericeous hairs. Flowers in leafy racemes, racemes arranged in fascicles of 1-3, yellow, standard glabrous or hairy only on the middle vein. Calyx $1-1.3 \mathrm{~cm}$ long, with short erect or patent hairs. Legume $1.5-2 \mathrm{~cm}$ long and $0.5-0.8 \mathrm{~cm}$ wide, more or less tomentose, some legumes sparsely hairy or glabrescent.

Taxonomy - Ch. korabensis clearly differs from Ch. albus, Ch. austriacus, Ch. tommasinii, Ch. rochelii, and related taxa by its glabrous standard and its flowers in leaf-axils, not in terminal heads. It differs from members of the Ch. eriocarpus agg. by the hair types of the leaf. Morphologically it is related to the Ch. ratisbonensis and Ch. triflorus agg. (Table 1).

Species of the Ch. ratisbonensis agg. (Ch. ratisbonensis, Ch. ruthenicus (Fisch. ex Wołosz.) Klásk., Ch. pineticola I. S. Ivchenko, etc.) are distributed in Eastern and Central Europe (Fig. 2) (CRISTOFOLINI 1991, ZIELIŃS KI 1975). Only a single occurrence of the group has been reported from the Balkans (Pirin Mts, Bulgaria; Assyov and Petrova 2012, Kuzmanov 1976) under the name Ch. ratisbonensis; however, the only voucher (Bulgaria, Znepole Region, Dragomanski Chepan, 29.05.2006, D. Dimitrov, SOM163768) is a fragmented specimen, insufficient for identification; consequently, the occurrence of Ch. ratisbonensis in Bulgaria (and in the Balkans) needs confirmation.

Ch. korabensis resembles Ch. ratisbonensis; since, the standard of Ch. korabensis is glabrous, stem and petiole are appressed hairy, and flowers are in the leaf axils. Contrarily, upper surface of leaflets in Ch. korabensis is hairy, while glabrous in $C h$. ratisbonensis, or rarely sparsely hairy.

From the same group, the upper surface of $C h$. pineticola, described from the surroundings of Kiev, Ukraine (IVCHENKO and SHEVERA 1992), is also hairy, but the leaflets are markedly larger, $1.5-3 \mathrm{~cm}$ long and $0.7-1.1 \mathrm{~cm}$ wide.

Species of the Ch. triflorus agg. are widely distributed in the Balkans (PIF Kó 2005b, SKALICKÁ 1986). Ch. korabensis can be distinguished from the taxa of this group by the appressed or erect hairs of stem and petioles (contrary to the patent hairs of the $C h$. triflorus agg.). Leaves of $C h$. korabensis are small and ovate, while leaves are orbicular and larger (1-2 cm long) in the Ch. triflorus agg.; however, taxa with smaller leaves are also known ("C. demissus Boiss.", "C. pumilus De Not."). As the older stems may be often glabrescent or very shortly hairy in the Ch. triflorus agg., the indumentum of young stems should be used for identification to avoid the misidentification of Ch. triflorus specimens as Ch. korabensis. 

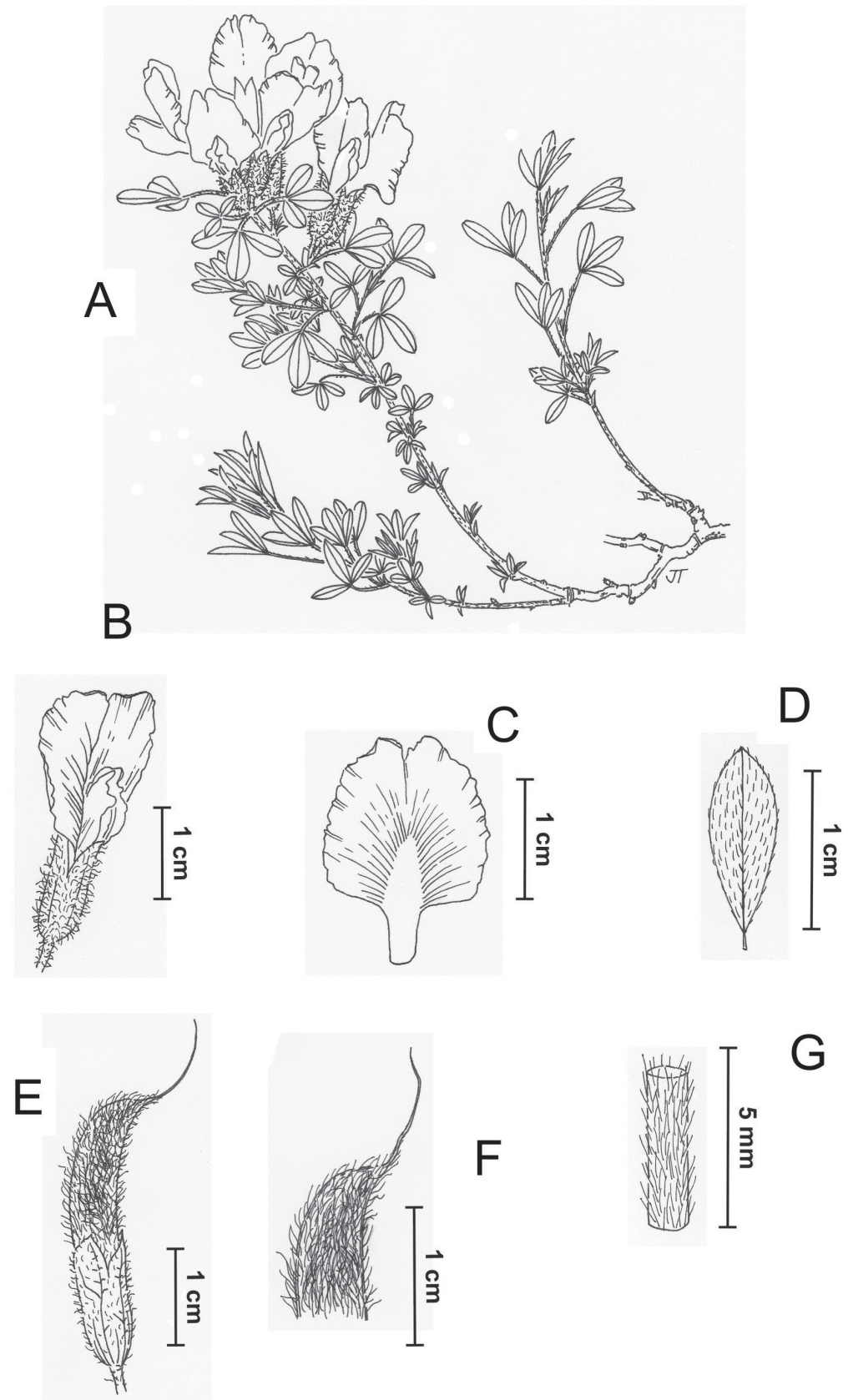

Fig. 1. Chamaecytisus korabensis - A: habit, flowering branch; B: calyx with flower; C: standard petal, adaxial surface; D leaflet upper surface; E-F: legume, G: young part of a branch with hairs (Drawing: Jana Táborská). 


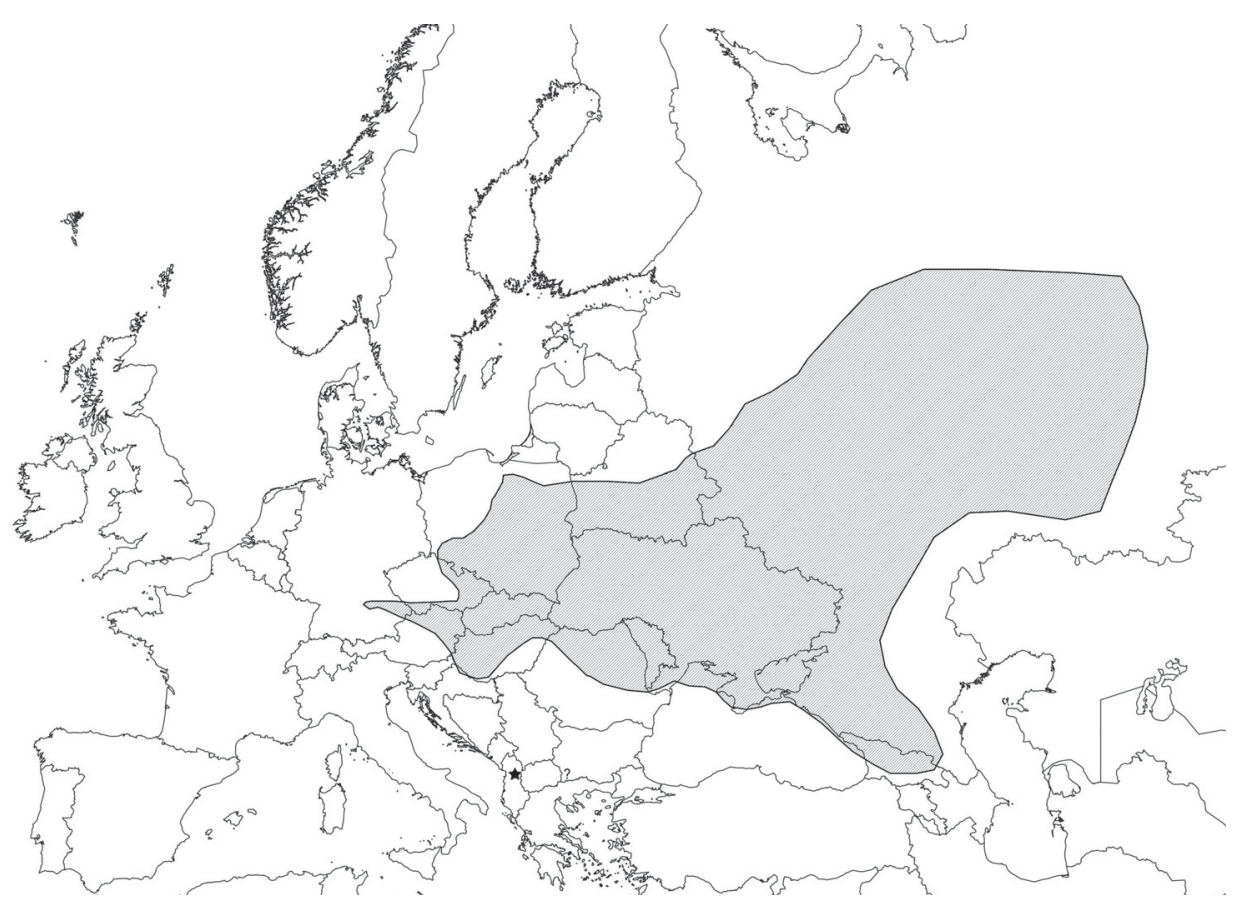

Fig. 2. Distribution of Chamaecytisus ratisbonensis agg. (incl. Ch. ruthenicus, Ch. pineticola, Ch. kreczetovici) follow ZIELIŃs KI (1975); black star: locality of Ch. korabensis.

Table 1. Diagnostic characters of species of Ch. ratisbonensis agg. and similar taxa

\begin{tabular}{|c|c|c|c|c|c|c|}
\hline & $\begin{array}{l}\text { Ch. kora- } \\
\text { bensis }\end{array}$ & $\begin{array}{l}\text { Ch. pine- } \\
\text { ticola }\end{array}$ & $\begin{array}{c}\text { Ch. ratisbo- } \\
\text { nensis }\end{array}$ & $\begin{array}{c}\text { Ch. elonga- } \\
\text { tus }\end{array}$ & $\begin{array}{l}\text { Ch. leio- } \\
\text { carpus }\end{array}$ & $\begin{array}{l}\text { Ch. polytri- } \\
\text { chus-wulffi }\end{array}$ \\
\hline $\begin{array}{l}\text { leaf upper } \\
\text { surface }\end{array}$ & hairy & hairy & glabrous & $\begin{array}{l}\text { hairy or } \\
\text { glabrous }\end{array}$ & $\begin{array}{l}\text { hairy or } \\
\text { glabrous }\end{array}$ & hairy \\
\hline $\begin{array}{l}\text { hairs on peti- } \\
\text { oles }\end{array}$ & $\begin{array}{l}\text { appressed } \\
\text { or erect }\end{array}$ & appressed & appressed & patent & appressed & $\begin{array}{l}\text { appressed } \\
\text { or erect }\end{array}$ \\
\hline legume surface & hairy & hairy & hairy & hairy & glabrous & hairy \\
\hline leaflets & $\begin{array}{c}\text { small, ovate, } \\
\text { obovate }\end{array}$ & $\begin{array}{l}\text { larger, } \\
\text { rounded }\end{array}$ & small, ovate & $\begin{array}{l}\text { larger, } \\
\text { rounded }\end{array}$ & $\begin{array}{l}\text { larger, } \\
\text { rounded }\end{array}$ & $\begin{array}{l}\text { small, } \\
\text { ovate }\end{array}$ \\
\hline $\begin{array}{l}\text { hairs on the } \\
\text { plants }\end{array}$ & $\begin{array}{c}\text { not } \\
\text { sericeous }\end{array}$ & sericeous & sericeous & $\begin{array}{c}\text { not } \\
\text { sericeous }\end{array}$ & $\begin{array}{c}\text { not } \\
\text { sericeous }\end{array}$ & sericeous \\
\hline distribution & Balkan & $\begin{array}{l}\text { Eastern } \\
\text { Europe }\end{array}$ & $\begin{array}{c}\text { Eastern } \\
\text { and Central } \\
\text { Europe }\end{array}$ & $\begin{array}{c}\text { Carpathian } \\
\text { Basin }\end{array}$ & Balkan & Crimea \\
\hline
\end{tabular}


Further, apparently intermediate taxa between Ch. triflorus agg. and Ch. ratisbonensis agg. have been described from Eastern Europe (Ch. elongatus (Waldst. and Kit.) Link, Ch. leiocarpus (A. Kern.) Rothm., and Ch. wulffi (V. I. Krecz.) Klásk.).

Ch. leiocarpus is a NW Balkan species with occurrences also in SW Transylvania. It can be clearly distinguished from the Ch. triflorus agg. by its appressed hairs on the stem, similar to Ch. korabensis; however, the surface of legume is glabrous in Ch. leiocarpus and hairy in Ch. korabensis, and similarly to the Ch. triflorus group, Ch. leiocarpus has large and orbicular, glabrous or shortly hairy leaves (PIFKó and BARINA 2011).

Ch. elongatus has been described from two distant parts of the Carpathian Basin (WALDSTEIN and KiTAIBEL 1805): a southern locality from region Banat at the border of Romania and Serbia and a northern one from Bereg County at the border of Hungary and Ukraine. The taxon was emended by JÁvo RKA (1925) and its lectotype was designated by CHRTEK and SKočDopolová (1982) from the Waldstein's collection ("Hungarica" PR: 155757d). A number of original specimens can be found in BP, PRC and PR ("Banatus" BP Kitaibel XXIV. 160; Romania, Caraş-Severin, Oravița, BP Kitaibel XXIV 161; “Comit. Bereghen”, P. Kitaibel, PRC and "Hungaria", A. Waldstein PRC). The designated lectotype, other original material and material from the southern locus classicus (Banat) are morphologically heterogeneous. The designated lectotype was presumably collected in the Bereg locality and it is identical with the glabrescent form of Ch. triflorus. According to JÁvo RKA (1925), presumably based on specimens BP Kitaibel XXIV/160 and 161 (cf. JÁvorka 1929, Pif Kó 2005a, 2007), Ch. elongatus in region Banat is appressed hairy with patent hairs on petiole. This region (Anina Mts, Romania; Deliblato sands, Serbia), is extremely rich in Chamaecytisus taxa, including Ch. ratisbonensis and Ch. triflorus; and specimens from the locus classicus of Ch. elongatus (Romania, Caraş-Severin, Ciclova Montană, N $45.029010^{\circ}$ E $21.752540^{\circ}, 339$ m s.m., D. Pifkó, 17.07.2008, BP 702190) can be both appressed and patent hairy. Consequently, the separation of Ch. elongatus from $C h$. triflorus is doubtful even following the emendation of Jávorka. Other authors (Kuzmanov 1976, Tzvelev 1987, 2002) treat Ch. elongatus as conspecific with Ch. glaber (L. f.) Rothm., which was described from Austria. Consequently, Ch. elongatus is a taxon with dubious status, possibly conspecific with Ch. triflorus, or is a local hybrid form of $C$. triflorus. According to our present knowledge, $C h$. korabensis clearly differs from Ch. elongatus by the patent hairs on petioles and larger leaves of the latter.

Two endemic taxa from $S$ Crimea, which seem to be intermediate between Ch. triflorus agg. and Ch. ratisbonensis agg. (Ch. polytrichus (M. Bieb.) Rothm. and Ch. wulffii (V. I. Krecz.) Klásk.), have been described from the same locality near the city of Yalta: "Habitat in Taurae maxime meridionalis montium altio- 
rum pinaetis." for Ch. polytrichus (MARSCHALl VON BIEBERSTEIN 1819); and "Tauria, supra Jalta, in pineto supra Utschan" for Ch. wulffi (KRECZETOWICZ 1940). The two taxa have mostly the same morphological characters, but the stem and petiole of $C h$. wulffii have appressed hairs, whilst Ch. polytrichus has patent hairs. According to our recent observations above Yalta (Ukraine: Crimea, Yalta, Ai-Petri plateau above Yalta on the cliff, N $44.501900^{\circ}$, E $34.084620^{\circ}, 1,244 \mathrm{~m} \mathrm{~s}$. m., Z. Barina, D. Pifkó and E. Andrik, 19.06.2010, nr. 17647, BP 758998, 759001, 759010-759013), specimens with patent and appressed hairs occur together without any other morphological differences.

Russian and Ukrainian texts (MosYAKIN and FEDORONCHUK 1999, TzVELEV 1987, 2002, YAKOVLEV et al. 1996) treat Ch. wulffii and Ch. polytrichus as independent species; however, their relationship requires further studies. According to our taxonomic concept (PIF Kó 2005b) any scattered records of Ch. polytrichus throughout Europe (CRISTOFOLINI 1991) need confirmation, all of them presumably refer to $C h$. triflorus or vernal forms of $C h$. supinus.

Ch. korabensis can be clearly distinguished from specimens discussed under the name $C h$. polytrichus by the appressed hairs, smaller legumes, and greyish opaque indumentum of the former.

Distribution and habitat-Mali i Bardhe, where evaporite domes of more than $1000 \mathrm{~m}$ thickness are outcropped and constitute a peculiar landscape with a number of karst forms (PARISE et al. 2008, VELAJ 2001).

Etymology - The plant is endemic to the western foothills of the Korab Mts.

\section{Chamaecytisus pseudojankae Pifkó et Barina, sp. nov.}

\section{(Fig. 3)}

Holotype: Albania, District of Korçë (Rrethi i Korçës), Thatë Mountains (Mali i Thatë), ca $1.7 \mathrm{~km}$ north of village "Zvezdë", on the southeastern ridge of Mount "Zvezdë" (1,833 m); in rocky grassland, on limestone, N 40.74774', E 20.86148 , 1,477 m; leg. Z. Barina, D. Pifkó and Cs. Németh, 25.05.2007, nr. 11736, BP 750418.

Isotype: W 2010-03241 (as Ch. jankae).

Paratypes: 1) Albania, District of Korçë (Rrethi i Korçës), Thatë Mountains (Mali i Thatë), ca $2.55 \mathrm{~km}$ west-northwest of village "Liqenas", ca $2.2 \mathrm{~km}$ east of the peak of Mount "Buz e Korutes" $(2,028 \mathrm{~m})$, on the southern ridge of the Mount at 2,034.7 $\mathrm{m}$ height; in karstic shrubland, N $40.79887^{\circ}$, E $20.87588^{\circ}, 1,539 \mathrm{~m}$; leg. Z. Barina and D. Pifkó, 22.05.2007, nr. 11593, BP 748705. - 2) Albania, District of Korçë (Rrethi i Korçës), Thatë Mountains (Mali i Thatë), ca 2.6 km east-northeast of village Podgorije, ca $700 \mathrm{~m}$ southwest of Mount "maja e Stanit" (1,911.6 m); in grassland, on limestone, $\mathrm{N} 40.82281^{\circ}$, E 20.83194' $1,802 \mathrm{~m}$; leg. Z. Barina, D. 
Pifkó and Cs. Németh, 20.05.2007, nr. 11455, BP 748704. - 3) Albania, District of Korçë (Rrethi i Korçës), Thatë Mountains (Mali i Thatë), ca $1.6 \mathrm{~km}$ east-northeast of village Podgorije, $c a 1.5 \mathrm{~km}$ west-southwest of Mount "maja e Stanit" (1,911.6 $\mathrm{m}$ ); in rocky grassland, on limestone, $\mathrm{N} 40.82039^{\circ}$, E $20.82228^{\circ}, 1,594 \mathrm{~m}$; leg. Z. Barina, D. Pifkó and Cs. Németh, 20.05.2007, nr. 11459, BP 748703.

Previous records - A number of specimens collected previously can be found in the TIR herbarium, identified as Ch. austriacus (Albania, County of Korçë, Mali i Thatë, kalkar, 1,700 m, 06.06.1973, K. Paparisto and Qosja Xh., TIR), as Ch. hirsutus (Albania, County of Korçë, Mali i Thatë, kalkar, 1,700 m, 06.06.1973, K. Paparisto and Qosja Xh., TIR; - Albania, County of Korçë, Mali Thatë, 2,134-2,284 m, 10.07.1974, V. Tartari, TIR; - Albania, County of Korçë, Mali Thatë, 1,884 m, 10.07.1974, V. Tartari, TIR), or as Ch. heuffelii (Wierzb.) Rothm. (Albania, County of Korçë, Mali Thatë: Maja e Ballamaqit kalkar, 1,600 m, 24.06.1971, J. Vangjeli and V. Tartari, TIR), from the same locality. Records from the Macedonian part of the mountains (Galičica Planina), have been reported under the name Cytisus austriacus var. calcareus (Velen.) Hayek (ČERNJAVSKI 1943, RECHINGER 1939, and vouchers - Republic of Macedonia, Southwestern, Ochrida, mt. Galičica (...), 10.07.1939, P. Černjavski, BEO 4451; - Republic of Macedonia, Southwestern, Ochrida: m. Galičica, Ason Dura, 05.08.1940, A. Pichler BEO 4452; - Republic of Macedonia, Southwestern Ochrida: m. Galičica: ad Ramne do, 1,500 m, 04.08.1940, A. Pichler BEO 4453; - Republic of Macedonia, Southwestern, Ochrida: m. Galičica Velestovski Trap, 07.08.1940, A. Pichler BEO 4450), and Ch. absinthioides subsp. rhodopeus (Teofilovski and Mandzukovski in TeofiLovski 2001); all refer to this new taxon.

Description - Low subshrub, 20-50(-70) cm tall. Young branches and petioles with appressed or erect hairs. Leaves trifoliolate; leaflets ovate or ellipticobovate, more or less mucronate, $0.3-0.5 \mathrm{~cm}$ wide and $1-1.5 \mathrm{~cm}$ long. Lower surface of leaves densely hairy, surface colour grey or yellowish-brown when dry (as characteristic for the Ch. eriocarpus agg.). Flowers yellow, in leafy racemes, arranged in fascicles of $1-5$ racemes, in leaf axils. Standard glabrous or hairy along the central vein. Calyx $1.3-1.6 \mathrm{~cm}$ long, with short erect or patent hairs. Legume $1.5-2 \mathrm{~cm}$ long, $0.4-0.6 \mathrm{~cm}$ wide with appressed hairs.

Taxonomy - Ch. pseudojankae is easily distinguishable from the Ch. supinus and $C h$. triflorus groups by its appressed hairs on the stem and petioles, scattered hairs on leaves, and its glabrous standard.

Ch.pseudojankae is apparently an intermediate species between the Ch. austriacus agg. and Ch. eriocarpus agg. The variously treated Ch. austriacus agg. is closely related to the Ch. albus group (PIFKó 2010). According to our species concept, taxa with yellow flowers, hairy standard, lanceolate leaves with sericeous, long hairs on upper surface belong to here. They flower during summer with a terminal capitate inflorescence, as "Cytisus arenarius Simonk.", "C. jankae 

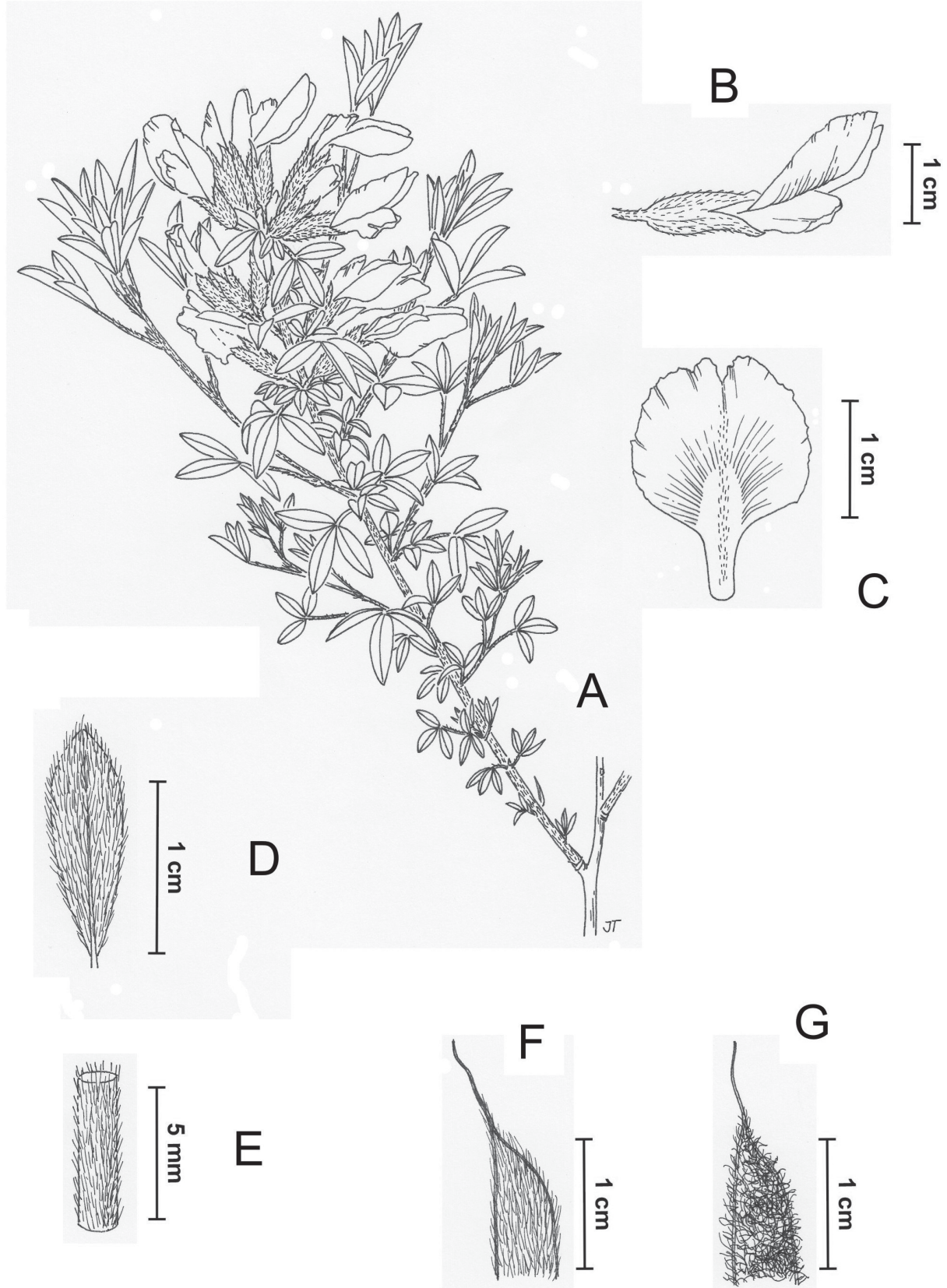

Fig. 3. Chamaecytisus pseudojankae - A: habit, flowering branch; B: calyx with flower; C: standard petal, adaxial surface; D leaflet upper surface; E: young part of a branch with hairs; F: part of legume of Ch. pseudojankae; G: part of legume of Ch. eriocarpus agg. (Drawing: Jana Táborská). 
Vel., "C. georgievii Davidov", “C. pseudopygmaeus Davidov”, “C. noeanus Rchb. in Noe", and " $C$. hirtellus Rchb.".

The Ch. austriacus agg. has a wide distribution from W Russia to Austria, with most of the Balkan reports being erroneous or in need of confirmation. From Albania, the only verified occurrence is on Mt Pashtrik (near the Albanian-Kosovan border).

Ch.pseudojankae differs from the members of the Ch. austriacus agg. by its flowering heads in the leaf axils (not terminal), by short ovate leaves (not oblong-lanceolate), and by the sericeous indumentum of the lower surface of leaves (Table 2).

Table 2. Diagnostic characters of species Ch. austriacus agg. and Ch. eriocarpus agg.

\begin{tabular}{|c|c|c|}
\hline & Ch. austriacus agg. & Ch. eriocarpus agg. \\
\hline inflorescence & flowers in heads & $\begin{array}{c}\text { flowers in leafy racemes mainly on } \\
\text { the upper third of stem }\end{array}$ \\
\hline hairs of stem & appressed or erect & mainly patent or appressed \\
\hline leaflets & lanceolate (rarely ovate) & ovate (rarely lanceolate) \\
\hline standard & densely hairy, with glabrous edge & only the midvein hairy \\
\hline leaf upper surface & $\begin{array}{c}\text { densely hairy with long and thin } \\
\text { hairs, but not completely hairy, } \\
\text { dried grey }\end{array}$ & $\begin{array}{l}\text { densely hairy with shorter hairs, } \\
\text { almost completely hairy, dried } \\
\text { yellowish-brown or grey }\end{array}$ \\
\hline
\end{tabular}

Due to the indumentum of the standard petal, we treat Ch. pseudojankae as related to the Ch. pygmaeus - eriocarpus - absinthioides group (shortly Ch. eriocarpus agg.) and not a member of the Ch. austriacus agg.

The Ch. eriocarpus agg. includes six species, with the following types, examined for this treatment (Table 3).

Cytisus absinthioides Janka, Oesterr. Bot. Z. 22: 175-176. 1872 - Lectotype (designated here): Bulgaria, Pirin, Gotse Delchev, 21.08.1871, V. Janka WUKerner 0033170. Text of label: "In collibus ad radices m. Perim. Dagh prope Nevrekop [...] orientalis.” K. I. Christensen designated as lectotype in 2004 on the sheets. Isolectotypes: BEOU (s. n.), BP 296809, GOET 005095, W Collectio Reichenbach fil. 44808, WU-Halácsy.

Cytisus eriocarpus Boiss., Diagn. Pl. Orient. ser. 1, 2: 11. 1843 - Syntypes: İzmir Province, Bozdağ, Mount Bozdağ [“Tmolus”], 00.06.1842, P. Boissier, GOET 005097, KW (Turchaninow Herbarium), KW (in world material, Ex Herbario Scegleewi), P 02952858.

Cytisus pygmaeus Willd., Sp. Pl., ed. 4 [Willdenow] 3(2): 1127. 1802 [110 Nov 1802] - Lectotype (designated here): Turkey, "Galatia”, D. Sestini, B-W13632-010; the label of lectotype is on the other sheet: B-W 13632-000, isotype: HAL 0100154 (U. Braun assigned as authentic specimen in the sheet). 
Cytisus rhodopeus J. Wagner ex Degen, Oesterr. Bot. Z. 43: 423. 1893; nom. inval. - Original material: Bulgaria, Rila ["Rhodopes centr."] Musala, alt. ca 1,500-2,000 m, 30.07.1892, J. Wagner (exsicc. 1892 No. 40), WU-Halácsy.

Cytisus smyrnaeus Boiss., Diagn. Pl. Orient. ser. 1, 2: 10. 1843 [Mar 1843] - Syntypes: Turkey, “montis Smyrneae” 00.06.1842., P. Boissier, BP 208133, FR 003144, GOET005096, KW (Turchaninow Herbarium), KW (in world material 2 sheets), P 02952937, 02952942, 02952944, 02952950, 02952951, 02952952, JE 00014575, 00014576, 00014577 designated by J. Müller (JE) on the sheet, W 9918, 0031010.

Cytisus tmoleus Boiss., Diagn. Pl. Orient. ser. 1, 2: 11. 1843 - Syntypes: Turkey, “Asia Minor”, E. Aucher (No. 1101), P 02952916, 02952919.

Table 3. Diagnostic characters of species of Ch. eriocarpus agg. based on type specimens

\begin{tabular}{|c|c|c|c|c|c|c|c|}
\hline & $\begin{array}{c}\text { Ch. pseudo- } \\
\text { jankae }\end{array}$ & $\begin{array}{l}\text { Ch. absin- } \\
\text { thioides }\end{array}$ & $\begin{array}{l}\text { Ch. erio- } \\
\text { carpus }\end{array}$ & $\begin{array}{c}\text { Ch. pyg- } \\
\text { maeus }\end{array}$ & $\begin{array}{l}\text { Ch. rho- } \\
\text { dopeus }\end{array}$ & $\begin{array}{l}\text { Ch. smyr- } \\
\text { naeus }\end{array}$ & $\begin{array}{l}\text { Ch. tmo- } \\
\text { leus }\end{array}$ \\
\hline $\begin{array}{l}\text { hairs of stem } \\
\text { and petioles }\end{array}$ & appressed & patent & patent & $\begin{array}{c}\text { ap- } \\
\text { pressed }\end{array}$ & patent & $\begin{array}{c}\text { ap- } \\
\text { pressed }\end{array}$ & $\begin{array}{c}\text { ap- } \\
\text { pressed }\end{array}$ \\
\hline hairs of calyx & $\begin{array}{l}\text { appressed } \\
\text { or erect }\end{array}$ & $\begin{array}{c}\text { patent or } \\
\text { erect }\end{array}$ & patent & erect & erect & patent & $\begin{array}{c}\text { ap- } \\
\text { pressed }\end{array}$ \\
\hline leaflets & ovate, & ovate & ovate & ovate & lanceolate & rounded & rounded \\
\hline legume & appressed & lanate & lanate & lanate & lanate & lanate? & lanate? \\
\hline locus classicus & $\begin{array}{l}\text { Balkan: } \\
\text { Albania }\end{array}$ & $\begin{array}{l}\text { Balkan: } \\
\text { Bulgaria }\end{array}$ & $\begin{array}{l}\text { Asia } \\
\text { Minor }\end{array}$ & $\begin{array}{l}\text { Asia } \\
\text { Minor }\end{array}$ & $\begin{array}{l}\text { Balkan: } \\
\text { Bulgaria }\end{array}$ & $\begin{array}{l}\text { Asia } \\
\text { Minor }\end{array}$ & $\begin{array}{l}\text { Asia } \\
\text { Minor }\end{array}$ \\
\hline
\end{tabular}

A detailed evaluation of the Ch. eriocarpus group has not yet been conducted. We studied the type material of Ch. tmoleus and Ch. smyrnaeus, two members of the Ch. eriocarpus group, but none of the original specimens of these taxa bear ripe fruits suitable for taxonomic investigation.

Ch. eriocarpus is distributed in Asia Minor and scattered in the mountains of the Balkans (Fig. 4) (Cristofolini 1991, Heywood and Frodin 1968). Most of the literature (Cristofolini 1991, Cristofolini and Troia 2006, Diklić 1972, GibBs 1969, HeYwood and Frodin 1968) treat the whole group under the name Ch. eriocarpus, while other authors treat it under the name Ch. absinthioides in Bulgaria and Macedonia (Assyov and Petrova 2012, Kuzmanov 1976, MiCEVSKI 2001). Based on the studies of the type material, the usually separated Ch. pygmaeus (Willd.) Rothm. (GibBs 1969, HeYwood and Frodin 1968, RoTHMALER 1944) also belongs to this group, contrary to the earlier concept as being a member of the Ch. austriacus group (CRISTOFOLINI 1991, PONERT 1973).

Based on the type material of the Ch. eriocarpus group, all members have densely hairy leaves on both sides, grey or yellowish brown when dry, with also 


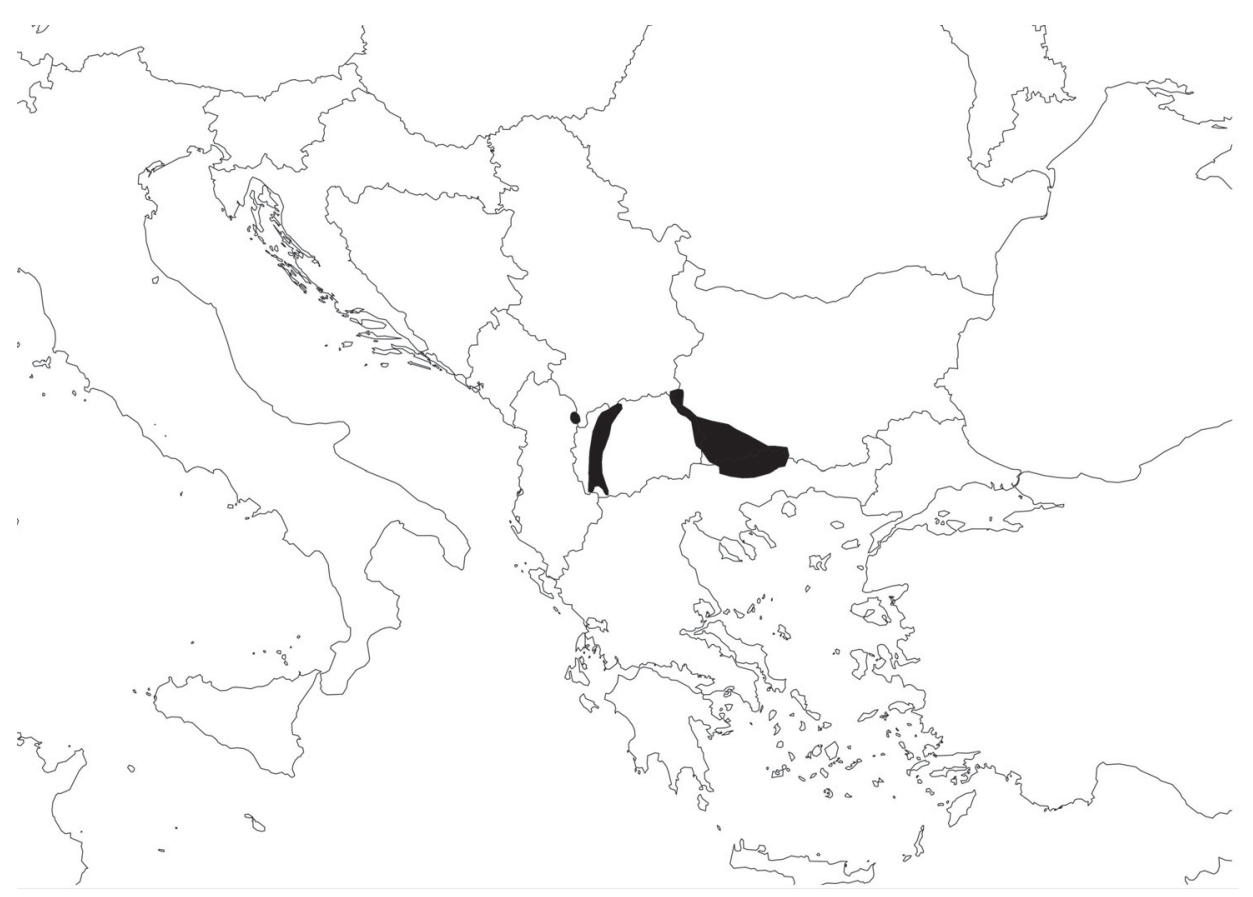

Fig. 4. Distribution of Chamaecytisus eriocarpus agg. in the Balkan Peninsula (follow Assyov and Petrova 2012, Teofilovski 2011 and STRID 1986).

patent hairs on the stem and petiole (except for Ch. tmoleus and Ch. smyrnaeus), flowers are in heads on the sides of the stem, standard hairy only along the midvein, the whole flower is yellow; the legume is tomentose. Contrarily, the legume of $C h$. pseudojankae is elongated and with appressed hairs on stem, calyx and legume.

Ch. tmoleus, treated usually as a species (AsCHERSON and GRAEBNER 1910, ROTHMALER 1944), as a subspecies (BRIQUET 1894, CRISTOFOLINI 1991) or as a synonym of Ch. eriocarpus (GibBs 1969), seems apparently the most similar taxon to Ch. pseudojankae; however, this taxon has been described on the basis of insufficient specimens ("specimen pessimum", BoIssiER 1843), which seem to be damaged or diseased specimens of Ch. eriocarpus. Specimens beyond the type material in the studied herbaria, identified as Ch. tmoleus, are not clearly identical with the type material; thus we have no information on the legume of $C h$. tmoleus; the taxon needs further clarification and cannot be conspecific with $C h$. pseudojankae, given the long distance separating their ranges.

Consequently, Ch. pseudojankae can be clearly distinguished from other species of the Ch. eriocarpus group by its hairy legumes, its appressed or erect 
hairs on stem and petioles. Ch. pseudojankae is not sympatric or connected with any other Chamaecytisus taxa with appressed hairs. The specimens of Ch. pseudojankae populations are uniform in appearance according to present studies of both living and herbarium specimens collected since 1939.

Distribution and habitat - Distributed in the range between Lake Prespa and Lake Ohrid, which is called as Thatë Mts in Albania and Galičica Mts in F.Y.R. of Macedonia. It occurs in dry, rocky grasslands on Mesozoic limestone.

Etymology - Previously, this population was thought to represent Ch. jankae.

\section{DISCUSSION}

Two new species of genus Chamaecytisus, i.e. Ch. korabensis and Ch. pseudojankae are described here. Both taxa are known from one isolated population, and morphologically are clearly distinct from any Chamaecytisus taxa in the Balkans. Due to the unique nature of the localities, a number of isolated occurrences of vascular plants are known from both localities. The population of $C h$. korabensis was discovered recently on the foothills of the Korab Mts, while that of Ch. pseudojankae is a well-known population on the Thatë Mts, with a number of gatherings from 1939.

Apparently similar specimens may occur extremely far from the locus classicus of the newly described taxa in morphologically diverse, often transitional populations, or even described as independent taxa. However, their relationship can be excluded as in the species groups vicariant taxa contacted with transitional zones are present and isolated forms with apparently geographically distant relatives can be originated by local speciation processes rather than survived relict populations.

Neither of the two recognised and described species can be clearly related to the known and more or less sympatric species groups and both taxa show the combination of relevant morphological characters of different groups within the genus.

The possibility of the new taxa being hybrids can also be excluded because of the lack of potential parent populations in the neighbouring areas and uniform appearance of plants in the populations.

Acknowledgements - The authors are indebted to Jana Táborská (Eger, Hungary) for preparing illustrations of the described taxa. We owe thanks to Csaba Németh (Budapest, Hungary) for his help in field work and László Lőkös (Budapest, Hungary) for his comments to the manuscript. We are also indebted to the curators and colleagues in the following herbaria, who enabled access to herbarium material (BEO, BEOU, KRA, KRAM, KW, PR, PRC, SO, SOM, TIR, W, WU). Authors work was supported by the Hungarian Scientific Research Fund (OTKA) 104443 grant. 
Összefoglaló: A cikk tartalmazza két új Chamaecytisus faj leírását Albánia területéről, ezek: Chamaecytisus korabensis és Chamaecytisus pseudojankae. A Ch. korabensis a Korab hegység evaporit előhegyein került először megfigyelésre, mely Albánia középső keleti részén található. A faj morfológiai alapon hasonlóságot mutat a $C h$. ratisbonensis fajcsoporttal, mivel tavasszal a hajtás oldalán virágzik, emellett kopasz vitorlája, rásimuló szőrủ szára van. Elkülöníti ugyanakkor a $C h$. ratisbonensis Kelet- és Közép-Európában honos taxonjaitól (Ch. ratisbonensis, Ch. ruthenicus), hogy a levél felszíne nem kopasz, hanem szőrös.

A Ch. pseudojankae Albánia délkeleti részén, illetve Macedónia nyugati részén, a Prespa és az Ochridi tó között húzódó Thatë, illetve Galičica hegység területén fordul elő. Ezt a populációt korábban számos egyéb más taxonnal azonosították. Morfológiai alapon a Ch. austriacus és a Ch. eriocarpus fajcsoport között áll. A Ch. pseudojankae a Kis-Ázsiában és a Balkánon honos $C h$. eriocarpus fajcsoport délkeleti tagja. A fajcsoport más taxonjaitól megkülönbözteti, hogy szára és termése rásimuló szőrü, míg a fajcsoport többi taxonjának termése gyapjasodó szőrü, a szár szőrzete pedig többnyire elálló.

A cikk a Ch. eriocarpus fajcsoport elemzése kapcsán két taxon tipizálását is tartalmazza, ezek a Cytisus absinthioides és a Cytisus pygmaeus.

\section{REFERENCES}

Ascherson, P. and Graebner, P. (1910): Cytisus. - In: Ascherson, P. and Graebner, P. (eds): Synopsis der Mitteleuropäischen Flora 6.2. Verlag von Wilhelm Engelmann, Leipzig, pp. 292-338.

Assyov, B. and Petrova, A. (2012): Conspectus of the Bulgarian vascular flora. Ed. 4. -Bulgarian Biodiversity Foundation, Sofia, 489 pp.

BARINA, Z. and Pif Kó, D. (2011): Contributions to the flora of Albania, 2. - Willdenowia 41: 139149. http://dx.doi.org/10.3372/wi.41.41118

Barina, Z., Pifkó, D. and Mesterházy, A. (2009): Contributions to the flora of Albania. - Willdenowia 39: 293-299. http://dx.doi.org/10.3372/wi.39.39208

Barina, Z., RakaJ, M. and Pif Kó, D. (2013): Contributions to the flora of Albania, 4. - Willdenowia 43: 165-184. http://dx.doi.org/10.3372/wi.43.43119

Boissier, P. E. (1843): Diagnoses Plantarum orientalium novarum. Ser. 1-2, 2. - B. Hermann, Lipsiae, $115 \mathrm{pp}$.

BRIQUET, J. (1894): Études sur les Cytises des Alpes maritimes comprenant un examen des affinités et une revision générale du genre Cytisus. - H. Georg. and Co., Genève et Bâle, 202 pp.

Čennjavski, P. (1943): Prilog za florističko poznavanje šire okoline Ohridskog Jezera. -Posebna izdanja, Srpska Kralj. Akad., Prirod. mat. spisi Beograd 35: 11-88.

CHRTEK, J. and SKočdopolová, B. (1982): Waldstein's collection in herbarium of the National Museum in Prague. - Acta Mus. Nat. Pragae 38: 201-238.

Cristofolini, G. (1991): Taxonomic revision of Cytisus Desf. Sect. Tubocytisus DC. (Fabaceae). - Webbia 45: 187-219. http://dx.doi.org/10.1080/00837792.1991.10670496

Cristofolini, G. and Troia, A. (2006): A reassessment of the sections of the genus Cytisus Desf. (Cytiseae, Leguminosae). - Taxon 55: 733-746. http://dx.doi.org/10.2307/25065647

Diklić, N. (1972): Chamaecytisus Link. - In: Josıfović, M. (ed.): Flore de Republique Socialiste de Serbie IV. Academie Serbe des Sciences et des Arts, Beograd, pp. 497-515.

GibBs, P. E. (1969): Chamaecytisus Link. - In: Davis, P. H. (ed.): Flora of Turkey 3. University Press, Edinburgh, pp. 16-21.

Heywood, V. H. and Frodin, D. G. (1968): Chamaecytisus Link. - In: Tutin, T. G. et al. (eds): Flora Europaea II. Univ. Cambridge Press, Cambridge, pp. 90-93. 
Ivchenko, I. S. and Shevera, M. V. (1992): Chamaecytisus pineticola Ivczenko: novyi dlya nauky vyd. (Chamaecytisus pineticola Ivczenko, a species new for science). - Ukr. Bot. Zhurn. 49: 84-86.

JÁvor KA, S. (1925): Magyar Flóra. [Flora Hungarica]. - Studium, Budapest, 1307 pp.

Jávorka, S. (1929): Kitaibel herbáriuma. [The herbarium of P. Kitaibel]. - Annls hist.-nat. Mus. natn. Hung. 26: 97-210.

Kreczetowicz, V. I. (1940): Rakitniki vostocnoj Evropy. - Bot. Zsurn., Moskva 25: 252-264.

Kuzmanov, B. (1976): Chamaecytisus Link. - In: Jordanov, D. (ed.): Flora Reipublicae Popularis Bulgaricae 6. Academiae Scientiarum Bulgaricae, Serdicae, pp. 74-119.

Marschall von Bieberstein, F. A. (1819): Flora Taurico-Caucasica exhibens stirpes phaenogamas, in Chersoneso Taurica et regionibus caucasicis sponte crescentes. - Typis Academicis, Charkouiae, $478 \mathrm{pp}$.

Micevs Ki, K. (2001): The flora of the Republic of Macedonia 1.5. - Macedonian Academy of Sciences and Arts, Skopje, pp. 1121-1430.

Mosyakin, S. L. and Fedoronchuk, M. M. (1999): Vascular plants of Ukraine. - National Academy of Sciences of Ukraine, Kiev, 345 pp.

PARISE, M., QIRIAZI, P. and SALA, S. (2008): Evaporite karst of Albania: main features and cases of environmental degradation. - Environm. Geol. 53(5): 967-974. http://dx.doi.org/10.1007/s00254-007-0722-x

Pif Kó, D. (2005a): Taxonomic revision and typification of Cytisus (Leguminosae) in the Herbarium Carpato-Pannonicum in Budapest (BP). - Annals hist.-nat. Mus. natn. Hung. 97: 23-28.

Pif Kó, D. (2005b): Adatok a hazai Chamaecytisus-fajok ismeretéhez II. - Flora Pannonica 3: 163-174. PIf Kó, D. (2007): Kitaibel's Cytisus taxa. - Studia bot. hung. 38: 11-32.

Pif Kó, D. (2009): Schur's Cytisus taxa. - Studia bot. hung. 40: 143-163.

Pifkó, D. (2010): A Heuffel-zanót (Chamaecytisus heuffelii [Leguminosae]) magyarországi előfordulásának megerősítése. (Confirmation of the occurrence of Chamaecytisus heuffelii in Hungary). - Dunántúli Dolgozatok (A) Természettudományi Sorozat 12: 51-60.

Pifkó, D. (2015): Index of scientific names of Chamaecytisus (Leguminosae) taxa. - Studia bot. bung. 46(2): 175-203. http://dx.doi.org/10.17110/studbot.2015.46.2.175

Pifkó, D. and Barina, Z. (2011): Chamaecytisus leiocarpus (A. Kern.) Rothm. In: Greuter, W. and RAAB-Straube, E. von (eds): Euro+Med Notulae, 5 [Notulae ad floram euro-mediterraneam pertinentes 27]. - Willdenowia 41: 130-131. http://dx.doi.org/10.3372/wi.41.41117

Pif Kó, D. and PAPP, L. (2006): Adatok a hazai Chamaecytisus-fajok ismeretéhez III. Chamaecytisus rochelii (Wierz.) Rothm. Magyarországon. (Data to the knowledge of the Hungarian Chamaecytisus species III Chamaecytisus rochelii (Wierz.) Rothm. in Hungary). - Flora Pannonica 4: 121-130.

Ponert, J. (1973): Neue taxonomische Kombinationen, Kategorien und Taxa vor allem der türkischen Arten. - Feddes Repert. 83: 617-644. http://dx.doi.org/ 10.1002/fedr.19730830902

Rechinger, K. H. (1939): Zur Flora von Albanien und Mazedonien. - Feddes Repert. 47: 165-179. http://dx.doi.org/10.1002/fedr.4870472205

Rothmaler, W. (1944): Die Gliederung der Gattung Cytisus L. - Feddes Repert. 53: 137-150. http://dx.doi.org/10.1002/fedr.19440530208

SkalickÁ, A. (1986): Chamaecytisus triflorus (Lam.) in der Tschechoslowakei. - Preslia 58: 21-27. STRID, A. (ed.) (1986): Mountain flora of Greece 1. - Cambridge University Press, Cambridge, 852 pp. Teofilovs KI, A. (2011): Contributions to the flora of the Republic of Macedonia. - Skopje, $142 \mathrm{pp}$.

ThIERs, B. (2008+) [continuously updated]: Index herbariorum: a global directory of public herbaria and associated staff. - New York Botanical Garden: published at http://sweetgum.nybg. org/ih/ [ accessed 25.04.2016]. 
Tzvelev, N. N. (1987): Chamaecytisus Link. - In: Fedorov, An. A. (ed.): Flora pratis Europaeae URSS. Nauka, Leningrad, pp. 216-225.

Tzvelev, N. N. (2002): Chamaecytisus Link. - In: Fedorov, A. (ed.): Flora of Russia. A. A. Balkema, Rotterdam, pp. 326-340.

Yakovlev, G. P., Sytin, A. K. and Roskov, Y. U. (1996): Legumes of Northern Eurasia. - Royal Botanic Gardens, Kew, 724 pp.

VelaJ T. (2001): Evaporites in Albania and their impact on the thrusting processes. - J. Balkan Geophys. Soc. 4: 9-18. http://dx.doi.org/10.1007/bf03175658

Waldstein, F. A. and Kitaibel, P. (1805): Descriptiones et Icones Plantarum Rariorum Hungariae. Vol. 2. - Typis Matthiae Andreae Schmidt, Viennae, pp. 105-221.

Zielińs Ki, J. (1975): Rodzaj Cytisus L. s. 1. w Polsce. [The genus Cytisus L. s. l. in Poland]. - Arbor. Kórnickie 20: 47-111.

(submitted: 14.03.2016, accepted: 03.06.2016) 